Ülevaade. Sõnavara uuenduste põhjusi ja levikuteid tuleb enamasti
otsida keelevälistest teguritest - kultuurikontaktidest ning neid mõju-
tavatest asjaoludest. See, et läänemeresoomlased on elanud mitme

LÄÄNEMERESOOMLASTE KEELEJA KULTUURIKONTAKTIDEST LAENSÕNADE LEVIKU PÕHJAL

\title{
Vilja Oja
} muukeelse võimu all, peegeldub otseselt sõnavaras. Millisest keelest sõna laenatakse, sõltub ka mõiste sisust ja laenamise ajast. Keskajal tõi palju saksa laene Eesti- ja Liivimaale hansakaubandus. Põllundusega seostuv sõnavara näitab ühtlasi aega ja suunda, kust ja millal mingi viljeluskultuur võis siinseile aladele tulla. Artiklis analüüsitakse indoeuroopa laensõnade levikut läänemeresoome murretes Euroopa keelte atlase (ALE) ja läänemeresoome keeleatlase (ALFE) materjali põhjal. Kaardid on aidanud mõnegi sõna päritolu määratleda.*

Võtmesõnad: indoeuroopa laensõnad, keeleatlased, keelekontaktid, sõnade levikukaardid, murdekeel, läänemeresoome keeled

\section{Sissejuhatus}

Keelekaart ehk keelenähtuste levikupilt võimaldab saada kiiresti väga mitmekesist informatsiooni, kui on olemas kaks eeldust: kaart on hästi koostatud ja kasutaja oskab seda interpreteerida. Keeles kajastub kõik inimeste elukeskkonnaga seonduv. Mõiste, mille väljendamiseks murdesõna mingil alal puudub, on olnud selle asukaile tundmatu. Sõnade levikukaardid mitte üksnes ei näitlikusta sõnade levikualasid, vaid aitavad määratleda leviku tuumala ja perifeeria, laenude levikuteed, mitmesuguste morfofonoloogiliste muutuste piirid ja palju muud, aga ühtlasi juhivad tähelepanu "tühjadele kohtadele", kust tuleks otsida täiendavat materjali veendumaks, kas antud mõistet sel alal tuntakse või ei. Käesolevas artiklis analüüsin laensõnade levikut läänemeresoome murretes, juhtides tähelepanu sellele, missuguseid järeldusi võib sõnavara leviku järgi teha. Et keelte ja murrete vahekorda on sageli raske üheselt määratleda, pole kõik lingvistid läänemeresoome keelte arvus üksmeelel.

* Artikkel on valminud Haridus- ja Teadusministeeriumi sihtfinantseeritava projekti SF0050037s10 ja Eesti Teadus- 
Siinses kirjutises lähtun enim aktsepteeritud, seitsme keele süsteemist, lugedes eri keelteks soome, isuri, vadja, karjala, vepsa, eesti ja liivi (vt nt Kettunen 1960, Laanest 1975, Tuomi 2004: 37-41, Viitso 1985).

Kõigi läänemeresoome keelte murdesõnavara on kaardistatud kahes keeleatlases: Euroopa keelte atlases "Atlas Linguarum Europae" (ALE) ja läänemeresoome keeleatlases "Atlas Linguarum Fennicarum" (ALFE). Mõlema teose autoriteks on rahvusvahelised töörühmad, mis koosnevad käsitletavate keelte/murrete asjatundjatest. Kaardistatav murdesõnavara on kogutud 20. sajandil. Kaartidele on keeleaines märgitud sümbolitega. Mõlemas atlases on mitut tüüpi kaarte, kõige enam onomasioloogilisi ja motiivikaarte, ent kaardistatud on ka muid keelenähtusi. Lisaks tavapärastele sõnavarakaartidele leidub ALFE-s näiteks semantika kaarte. Mõlema atlase kaartide juurde kuuluvad selgitavad kommentaarid. Mõni ALE kommentaar küündib pika ja põhjaliku uurimuse tasemele. ALFE-s on eelistatud lühikesi kommentaare. Ühe keele murdeatlased on ilmunud eesti, soome ja karjala keele kohta (Bubrih 1997, Kettunen 1940 ja 1959, Leskinen 1992, Saareste 1938, 1941, 1955). Käesolevas kirjutises on kasutatud peamiselt ALE ja ALFE jaoks kogutud sõnavara.

ALFE 1. ja 2. osa materjali on analüüsitud paljudes keeleteaduslikes artiklites Selle põhjal on avaldatud ka ülevaatlikke kirjutisi, mis näitavad läänemeresoome keelte omavahelisi suhteid (nt Oja 2003, Tuomi 2005), keeleatlases kajastuvat foneetilist ja grammatilist infot (Neetar 2005, Viitso 2005), omasõnavara ja laenude vahekorda (Laanest 1995, Suhonen 2005, Tuomi 2009) jm. ALE ja ALFE kaarte võrdlevalt pole käsitletud. Siinses artiklis ei ole tähelepanu all läänemeresoome hõimude väga vanad kontaktid germaani, balti ja lääneslaavi hõimudega, mis toimusid enne meie ajaarvamist. Tõenäoliselt jagunes läänemeresoome algkeel iseseisvateks hõimukeelteks umbes meie ajaarvamise algul (Laanest 1975: 18). Kuna atlastes, mille materjalile toetun, on kaardistatud erinevate läänemeresoome keelte sõnavara, saame jälgida hilisemaid, pärast eri keelte kujunemist toimunud kontakte, arutleda nende põhjuste ja tulemuste üle.

\section{Uuenduste teke ja traditsioonilised mõjupiirid}

Tihedad kontaktid mitme indoeuroopa keelega on tingitud juba läänemeresoome keelte ala geograafilisest asendist: idas räägitakse ida-slaavi, lõunas balti, põhjas ja läänes peamiselt germaani keeli. Sõnavara uuenduste põhjusi ja levikuteid tuleb enamasti otsida keelevälistest teguritest. Uued sõnad tulevad käibele tavaliselt koos kultuuriliste uuendustega (vt ka Tuomi 2004: 29 ja 2009: 252 jj). Tiit-Rein Viitso on läänemeresoomet tabavalt nimetanud kultuurigeograafia seisukohalt lääne ja ida kohtumisalaks, lisades, et selle lääneosa jaguneb valdavalt rootsimõjuliseks ja saksamõjuliseks, kuigi üksikud laenud võivad vahel olla jõudnud üle traditsiooniliste mõjupiiride (Viitso 2005: 48-49). Ajalookäiku arvestades ei saagi see teisiti olla, kuna suurte naabrite võitlus läänemeresoomlaste alistamiseks on jätnud jälje nii siinsesse kultuuri kui ka keelde. Innovatsioonide juures pole tähtsusetu kontaktis olevate isikute ja keelte staatus: kõrgema prestiižiga keel ja kultuur on enamasti andja ning madalamalt hinnatud keel/kultuur vastuvõtja rollis. See, et läänemeresoomlased on elanud mitme muukeelse võimu all ning nende idarühma 
asualad kuuluvad seni Venemaa koosseisu, peegeldub ka sõnavaras. Isegi siin näidetena lisatud vähestel joonistel paistab silma, et soome keelde on eelmisel aastatuhandel enim indoeuroopa laene tulnud rootsi keele kaudu, eesti keelde saksa või alamsaksa keelest (alati pole võimalik määratleda, kummast), liivi murretes on suur osakaal nii alamsaksa kui ka läti laenudel, kusjuures viimaste seas on üle 2500 uue laenu (Suhonen 1973). Läänemeresoome idarühma keelte, karjala ja vepsa peamine laenuandja on olnud vene keel.

Traditsioonilist kolmikjaotust näeme mõistet 'palvetama' väljendavate sõnade levikukaardil (vt joonis 1; täpsemalt vt ALFE 2: 325-327, Laanest 2000: 44-47). Läänemeresoome lääneosas on levinud kaks verbi: ruko-tüvest lähtunud variandid soome, isuri ja vadja keeles ning *palvo- tüvest lähtunud sõnad eesti, liivi ja vadja keeles. Mõlemad väljendavad ka üldmõistet 'paluma, anuma' (SKES: 858). Läänemeresoome idarühma keeltes kasutatakse moli- tüvega vene laensõna (< vn молиться 'palvetama') ning vene tõlkelaene, nagu ristas jt (< vn креститься 'ristimärke tehes palvetama') vepsa keeles ning kummarrella 'kummardades palvetada' Tveri ja Novgorodi oblastis kõneldavates lounnakarjala murretes. Lisaks eelmainituile on mõnes karjala murdes tarvitatud aihe-tüvest tuletatud refleksiivset verbi aihella või aihostada 'jumalat paluda; soovida; ennustada' (vrd soome aihe 'põhjus, motiiv; alge'). Lõunavepsa murdes märgib palvetamist verb loita loičta, mille häälikulised vasted soome, karjala ja eesti keeles tähendavad 'loitsida'. Verbidega kõrvuti kohtame verbi ja nimisõna ühendeid, nt eesti palubjumalat, karjala panna malittua, lugie molittuo 'palvet lugeda'. Sõnade valikut mõjutab kõneleja usuline kuuluvus. Näeme, et nimetamismotiivi alusel jaguneb läänemeresoome keeleareaal sisuliselt kaheks. Mõned karjala ja vepsa sõnad väljendavad vene õigeusu kombeid järgivat fü̈̈silist tegevust (kummardamist, ristimärkide tegemist), lääne pool, luteri ja Rooma katoliku kiriku valdustes seda ei esine. Karjala ja vepsa aladel säilis kaua muinasusk ja ortodokssus jäi teatud mõttes võõraks (Harva 1932). See ilmneb murretes, kus palvetamist nimetatakse loitsimiseks, ennustamiseks vms, mis kuulus nende vana usu kommetesse. Ortodokssed isurid ja vadjalased pole samuti vene terminit omaks võtnud, vaid kasutavad soome või eesti keelega sarnaseid verbe.

Pole harv juhus, kus sama algupäraga indoeuroopa tüvi on läänemeresoome murretesse laenatud erinevaist indoeuroopa keeltest. Nagu näitavad germaani päritoluga klee-/klöö-tüvelised nimetused, on teatud liiki kultuurristik tulnud läänemeresoome alale kolmest suunast: Põhja-Soome ja Somero murde klööveri/ lööveri on laenatud Skandinaaviast, vrd rootsi klöver, norra kløver id. Ingerimaal ja karjala ning vepsa murretes on kasutusel vene laen: karjala ja vepsa klever, soome ja karjala klieveri, kleeveri, soome ja vadja kleiveri < vn клевер. Üksikutes eesti murretes on kasutatud saksa laenu klee < sks Klee (vt ka ALFE 2: 57-62).

Kartul levis läänemeresoomlaste asualal 18. saj, esmalt mõisates ning kloostrites, kust seda rahvale (algul tagajärjetult) propageeriti, ja muutus üldiseks alles 19. saj (Aalto 2008, ENE 4: 353). Seega on meie lähisugukeeltes kartulit tähistavad laensõnad suhteliselt hilised ning küllap mõjustatud propageerijate keelest. Läänemeresoome alal on laialt levinud kolme indoeuroopa tüvega sõnad (vt ALFE 2: 48-51). Skandinaavia laen pota- esineb peamiselt Põhja- ja Ida-Soomes ja rootsi laen peruna Lääne-Soomes. Alamsaksa sõnast kartuffel pärinevaid nimetusi kasutatakse läänemeresoome ida- ja lõunarühma keeltes (vt ka Saareste 1955: 15) ning need on tulnud mitut teed kaudu. Eesti keel on laenanud sõna otse alamsaksa keelest 
või saksa sõnast Kartoffel (EEW: 719), kuid võru kardohk variandid pärinevad vene keelest (Must 2000: 87). Idapoolsed läänemeresoome keeled, karjala ja vepsa ning soome kagumurded on saanud selle sõna samuti vene keele kaudu (< vn kartoška). Eesti Lutsi murrakus ja liivi Salatsi murdes on kasutatud lätipäraseid nimetusi: Lei kartupel', liivi kartup, tartup (< läti kartupelis < asks kartuffel) (Suhonen 1973: 126, Vaba 1997: 289). Saksa Kartoffel pärineb Põhja-Itaaliast, kus kartulit oli sarnaselt artišokiga murdekeeles nimetatud tartufolo või (Friuli ladiini keeles) Cartùfule. Esmalt naabruses kõneldud saksa murdesse laenatud sõnas toimus edasise leviku käigus rida häälikulisi ja vormilisi muutusi (Škofic 2009: 230-231). Ka läänemeresoome murretes on sellest tüvest tekkinud väga palju sõnavariante (vt ALFE 2: 48-55).

\section{Muud laenud}

Lisaks saksa mõjule on eesti keeles suur hulk vene, rootsi ja läti laene (vt Must 2000, Raag 1988, Vaba 1997). Soome keele innovatsioonide allikana 19. saj on kõrvuti rootsi keelega mainitud saksa ning osaliselt vene keelt, 20. saj lõpupoole aga on esiplaanile tõusnud inglise ja angloameerika mõju (Sajavaara 1986: 65). Ka ALE ja ALFE kaartidel näeb üsna palju "traditsiooniliste mõjupiiride" nihkumisi. Kui läänemeresoome põhjarühm jaguneb enamasti lääne ja ida mõjupiirkonnaks, siis Soome lahest lõuna poole jäävad keeled - eesti ja liivi ning vadja ja isuri - võivad kuuluda nii lääne kui ida mõjusfääri.

ALE kaardil, mis kujutab kapsa nimetusi Euroopa keeltes, "kohtuvad" läänemeresoome alal kaks indoeuroopa sõnatüve (ALE 1, 7: kaart 76). Suur osa Soomest on kaardil tühi, kuna kapsas ei kuulu soome traditsiooniliste viljeluskultuuride hulka, kuid Soome ida- ja edelaosas ning lääne- ja lõunarannikul, kus kapsast kasvatatakse, kasutatakse skandinaavia laenu kaali, mis on siit laenatud ka isuri keelde; vrd rootsi, norra, taani kål, islandi kál id., norralapi kāllâ jt (SSA 1: 263, SKES: 134). Laenu aluseks olnud sõnatüvi on Euroopas laialt levinud germaani ja romaani keeltes, vrd nt sks Kohl, hisp col vanaingl cāl, mis pärinevad ladina sõnast caulis: vrd ka ladina caulus, kreeka kaulós jt (vt Beltechi, Mocanu 1997). Eesti sõna kapsas (jt murdevariandid) nagu ka karjala kapusta, vepsa kapust ning isuri ja vadja kapussa on laenatud vene poolelt < vn кanycma (EEW: 700). Liivi kāpst on viimastega sama algupära, kuid laenatud läti keele vahendusel, vrd läti kāposti $(<$ vn). Sellest tüvest tulnud kapsa nimetusi esineb peale slaavi ja balti keelte veel paljudes Euroopa keeltes, nt ingl cabbage, sks Kappes, Kappus (< kappaz, capuz), ungari káposzta jt, uurali keeltest veel neenetsi, volga ja permi keeltes. Need on tulenenud ladina sõnast caput 'kapsas; pea' (vt ALE 1, 7: kaardi 76 legend, Buck 1988: 373).

Millisest keelest sõna laenatakse, sõltub muidugi ka mõiste sisust ja laenamise ajast. Mõistet 'palvetama' tähistavad sõnad kinnitavad fakti, et ristiusk toodi karjala ja vepsa aladele Venemaalt, kui läänepoolsete keelte verbid viitavad Lääne-Euroopa mõjule. Põllundusega seostuv sõnavara näitab ühtlasi aega ja suunda, kust ja millal mingi viljeluskultuur võis siinseile aladele tulla. Kapsakasvatuses näib Soome olevat eeskuju võtnud Skandinaaviast, teised läänemeresoome asukad aga balto-slaavi rahvastelt. Hiliste kultuuride, kartuli ja kultuurristiku leviku kohta on piisavalt 
kirjalikku teavet, kinnitamaks, et uus sõna võeti omaks koos uue taimega. Kõik saani nimetused eesti murretes on vene laenud: saan, kresla, kresku, krõsna, jassik, kibitka, vassuk. Seevastu karjala ja vepsa keeles kasutatakse soome keelest laenatud rootsi päritoluga sõna korja variante (ALFE 3: 186-193).

Laensõnadel on murretes tavaliselt palju häälikuvariante. Sõnavarakaartidele märgitakse need sageli ühesuguse sümboliga, võimaldamaks hoomata lekseemi leviku ulatust. Kui sama tüvi on laenatud erinevatest keeltest, on nende levik vaatlusalustes atlastes esitatud erinevate, kuid ühte sarja kuuluvate märkidega. Ühelt poolt eeldab see kaardistajalt etümoloogilisi teadmisi, teiselt poolt aga viib levikupilt mõnigi kord sõna päritolu avastamiseni. Näiteks kui deskriptiivsõnaks või genuiinseks tuletiseks peetud termin esineb ainult läänemeresoome ala servas või teatud laenude tavalisel levikualal, on põhjust otsida selle võimalikku sugulust või analoogiat indoeuroopa keelte sõnavarast. Kui ALFE kaardil esitatakse üldistatud sõnakuju, on täpsed murdekeelendid loetletud kommentaaris. Paljudel juhtudel saab häälikulisi ja vormilisi muutusi jälgida lisakaartidelt. Viimased omakorda võivad olla abiks ka sõnade etümologiseerimisel.

\section{Uuenduste keskused ja levikuteed}

Uuenduste teke on seotud kontaktidega ning levikusuund keskustest ääremaade poole. Uuenduste ja keelekontaktide keskused ning nendest lähtuvad liikumisteed seostuvad eelkõige kaubandusega. 13.-16. saj kontrollis Lääne- ja Põhjamere kaubandust Põhja-Saksa, Madalmaade ja Liivimaa kaubalinnade ühendus Hansa Liit, millel olid tugikontorid mitmes välisriigis. Tähtsaim kaubatee kulges liinil Novgorod-Tallinn-Lübeck-Hamburg-Brügge-London (ENE 3: 307). Hansa idatiival, Eesti ja Liivimaal paiknes 3 suurt kaubalinna - Riia, Tallinn, Tartu - ning kümmekond väiksemat, mis kõik olid transiitkaubanduse keskusteks Venemaa ja Lääne-Euroopa vahel. See aitab selgitada küsimust, miks mitmed uuendused on tulnud kõigepealt eesti keelde, levides siit hiljem teistesse läänemeresoome keeltesse. Teiselt poolt on hansakaubandus üheks oluliseks põhjuseks, miks paljusid tööstuskaupu tähistavad eesti ja liivi keeles saksa laensõnad. Joonis 2 näitab eri keeltest laenatud seebi nimetuste levikut. Läänemeresoomlased pesid vanasti pesu tuhaleelisega, seep toodi siia esmalt kaupmeeste poolt. Soome-, eesti- ja liivikeelsed seebi nimetused lähtuvad ühest germaani tüvest < germ *saipōn (SSA 3: 143). Soome murretes varieerub tüve astmevaheldus ja lõpusufiks (vt ALFE 1: 201-202). Eesti seep on laenatud alamsaksa keelest < asks sēpe (EEW: 2735, SKES: 947 ja 1009). Liivi zeep on samuti alamsaksa päritoluga, ent heliline alguskonsonant osutab läti mõjule (ALFE 1: 203). Idapoolsetes läänemeresoome keeltes kasutatakse vene laenu: soome, karjala, vepsa, isuri, vadja muila, muiljms < vn мыло. Huvitav on siinjuures mainida, et seebi aseaine, tuhaleelise nimetus põhja- ja keskvepsa murdes, mugl on varasem laen samast vene tüvest (Kalima 1952: 123-124, ALFE 1: 205-206). Lõunaeesti keeles (peamiselt tartu ja võru murdes) ning Kodavere murrakus märgib sõna mugel (mugla, mukl) seebipära, soopa (vt ka VMS 2: 35, Wiedemann 1973: 609). Siia on see laenatud vene keelest, vanast Pihkva murdest (Ojansuu 1922: 139).

Soomes oli 15. saj kaks Hansa tugikontorit, Turu ja Viiburi. Need piirkonnad on samuti olnud keeleuuendustele altid. Viiburist Novgorodi kulges kaubatee üle 
Laadoga. Viiburist Laadogasse suundunud veetee lõpus Vuokse suudmeala lähistel asus keskajal ümbruskonna suurim kaubanduskeskus, tollal Novgorodi vabariigi valdusse kuuluv Korela (soome Käkisalmi, rootsi Kexholm), kust tehti kaubaretki põhja ja lõunasse, Venemaale ja Rootsi. On täheldatud, et Karjala maakitsuselt on levinud laene (eriti semantilisi laene) nii põhja-karjala murretesse kui ka loode suunas - soome murretesse, mõnel juhul kuni Soome ida- ja põhjapiirini välja (vt Leskinen 1992: 3, Tuomi 2009: 255-257).

\section{Sõnalevik ja asustus}

Keelekaardid näitavad et laenude levikupiirid ei kattu tihti haldusalade piiridega, vaid sageli on uuendused leidnud aset mingil murdealal. Näiteks lõunavepsa murdes tarvitatakse palvetamise kohta oma sõna, kui kesk- ja põhjavepsa murretes on üle võetud vene väljendusviis. Mõne mõiste puhul on vanem laensõna asendatud uuemaga või kasutatakse paralleelselt eri päritoluga sünonüüme (nt vepsa risttaste, mol'daste 'palvetama'). Eesti idapiiril ja soome Ingeri murdes esineb rohkem vene laene kui nende keelte aladel tervikuna (nt kartuli nimetused).

Rootsi valitsuse ajal on eesti ja soome keelde tulnud terve hulk sõjaväge ja riigikorraldust puudutavat sõnavara, ent tavaeluga seostuvaid sõnu võeti üle kaupmeestelt ning Soomes ja Eestis elavalt rootsikeelselt lihtrahvalt. Soome ja põhjaeesti murretes on uuem ämbri nimetus germaani keeltest laenatud sõna: eesti ämber (murdeis ka ämmer, ämbel), soome ämpäri << kreeka amphoréus 'kahe käepidemega (nõu)' (vt joonis 3; ALFE 1: 198-199). Soome ämpäri, mis vanasti märkis kalakauplemise mõõdunõud, on tulnud rootsi keelest < rootsi ämbar id. (SKES: 1872-73). Eesti sõna suhtes on avaldatud kahtlust, kas see on laenatud rootsi või alamsaksa keelest (vrd asks emmer, ammer, amber id.) (SSA 3: 498). Levikukaardi põhjal võiks järeldada, et eesti keeles on sõna hakanud levima Tallinnast igas suunas, asendades vanemaid ämbri nimetusi, mis säilisid äärealadel: raand läänes ja pang ida ning lõuna pool. See, et innovatsiooni lähtekohaks pole tavaline rootsi laenude ala, kallutab otsustama alamsaksa etümoloogia kasuks (Saareste 1924: 239). Sõna esmane kasutus kalakaupmeeste mõõdunõuna viitab aga rootsi keele poole. Keskajal olid Eesti ja Soome rannikualad ja väikesaared asustatud rootslastega, kes elatusid meresõidust ja kalapüügist ning neist sisemaa pool elanud eesti ja soome soost põlluharijad puutusid merendusmõistetega kokku esmajoones rootslaste kaudu. Eestirootsi laenudest eesti keeles moodustab märkimisväärselt suure osa just merendus- ja kalandusalane sõnavara (Ariste 1933).

Soomerootsi mõju ilmneb ootuspäraselt enim Edela-Soome, Uusimaa ja Pohjanmaa ranniku rootsikeelse asustusega alade naabruses olevates soome murretes. Teiselt poolt kinnitavad sõnade levikukaardid ilmekalt Botnia lahe tähtsust skandinaavia ja soome keelekontaktides. Siit on skandinaavia, eelkõige rootsi laenud tulnud Oulu ning levinud piki Oulu jõge selle naaberaladele ning jõudnud isegi soome kagumurretesse. Üht tüüpilist näidet suhteliselt uue rootsi laensõna niisugusest levikust on kujutatud joonisel 4. Põhja- ja Kesk-Pohjanmaal ning põhjapoolseis savo murretes märgib rohelist värvust adjektiiv krööni (murretes ka rööni, ryöni, rööninen, ryöninen) < rootsi grön 'roheline' (täpsemalt vt ALFE 2: 279 ja 282, Koski 1983: 146, SKES: 932, SSA 1: 423). Sealtsamast, Botnia lahe 
põhjaosast on innovatsioonid liikunud ka põhja suunas, Länsipohja ja Peräpohjala murretesse, nt krööni (vt joonis 4), ämber (vt joonis 3), klööveri, ehkki viimane võib olla ka norra laen, vrd norra kløver (ALFE 2: 60). Neidsamu kolme mõistet väljendavad läänemeresoome idaosas hilised vene laenud: 'roheline' - karjala, vepsa źelonoi, źelonane jt < vn зелёный (vt ALFE 2: 279, 282); 'ämber' - soome vietra, karjala viedru, viedra, vepsa vädr < vn ведро (ALFE 1: 198-199, SKES: 1731); 'ristik' - karjala kleever, kliever jt < vn клевер (ALFE 2: 57-62). Vene võim, riigikeel ja segaasustus läänemeresoome idatiival on toonud sealsetesse keeltesse eriti rohkesti uuemaid vene laene. ALFE 1. osa materjali analüüsides leidis toimetaja Seppo Suhonen (2005), et seal kaardistatud karjala ja vepsa sõnavarast on umbes 2/3 siiski algupärane ja 1/3 laenatud, ent laenud pärinevad enamasti vene keelest.

Kõige keerulisemad laenusuhted valitsevad isuri ja vadja keeles, kus ristuvad kolme nn kõrgema prestiižiga naaberkeele: soome, eesti ja vene mõjutused. Näiteks saani nimetatakse vadja, isuri ja soome Ingeri-murretes saani, vrd eesti saan, saań ja liivi saań (ALFE 3: 186-193). Kitse tähistavad kolm laenu: isuri ja vadja kili < soome; vadja kitsi, isuri kits (Ala-Laukaa) < eesti; vadja voho, isuri voohi (Hevaha) < balti (ALFE 3: 138-140). Palvetamist väljendavad nii isuri kui ka vadja keeles kaks verbi: soome keelega sarnane rukoilla sõna ja eesti keelega sarnaselt palvoa verbi variant. Seepi (vt joonis 2) ja kultuurristikut märgivad isuri ja vadja murretes vene laenud. Teiselt poolt on mõnikord just isuri ja vadja murretes säilinud omapärane keeletarvitus, genuiinne sõna (nt muna 'kartul') või vanem laen (nt isuri voohi, vadja voho 'kits').

\section{Kokkuvõtteks}

ALFE kaardid kajastavad keelendite leviku kaudu kõigepealt läänemeresoome murrete omavahelisi suhteid, uuenduste keskusi ja levikuteid ning vanema murdega kohti, sama algupäraga sõnade semantilisi arenguid lähisugukeeltes, aga ka palju huvitavat ja vajalikku teavet mitmesuguste murdenähtuste kohta. Laensõnade päritolu osutab kultuuriinnovatsioonide lähtekohtadele. Eesti ja liivi keelde on hulk laensõnu toonud keskaegne hansakaubandus. Soome murretesse on palju laene tulnud Botnia lahe kaudu ja Loode-Laadoga kaubanduskeskusest karjala maakitsusel. Rootsi laensõnu on nii eesti kui ka soome murdeisse sugenenud rootslastega asustatud rannikualadelt. Uuemate laenude levik näitab väga tugevat vene mõju karjala ja vepsa murretes.

ALE hõlmab 51 riigi territooriumil kõneldava 22 keelerühma keeli, mis kuuluvad kuude keelkonda ning selle atlase kaardid võimaldavad jälgida Euroopa keelte ja murrete vahekordi üldisemas plaanis. Sõnade ja nende tähenduse sarnasused ning erinevused reedavad kõnelejate ajaloolist, kultuuriloolist, etnilist ja geograafilist tausta. ALE kaartide alusel saab teha järeldusi läänemeresoome kontaktide kohta indoeuroopa naabritega, täpsustada sõnatüvede päritolu, aduda nende levikupiirkondi ja -ulatust Euroopa territooriumil. Kui läänemeresoome keeltes esineb mitme eritüvelise indoeuroopa laenu kitsas levik, siis ALE kaardilt selgub tihti, et läänemeresoome keeleala jääb nende, tegelikult laialt levinud laenude ääremaile, kus mitmest suunast tulnud sõnad kokku saavad. 


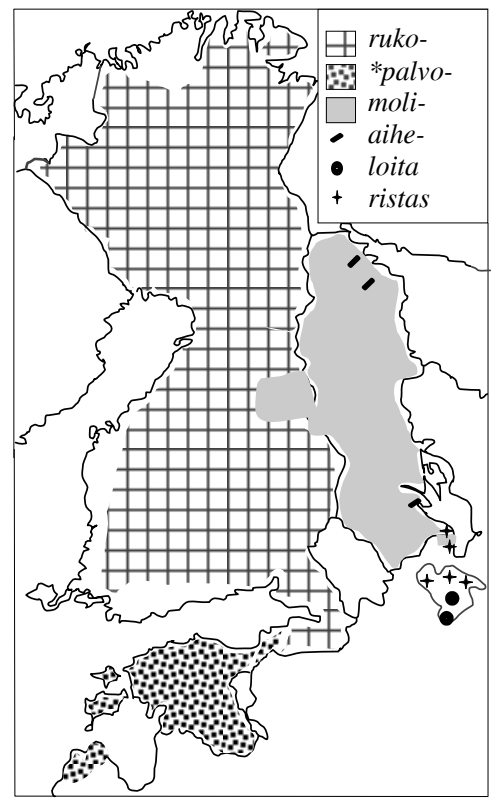

Joonis 1. 'palvetama' (vt ALFE 2: 325)

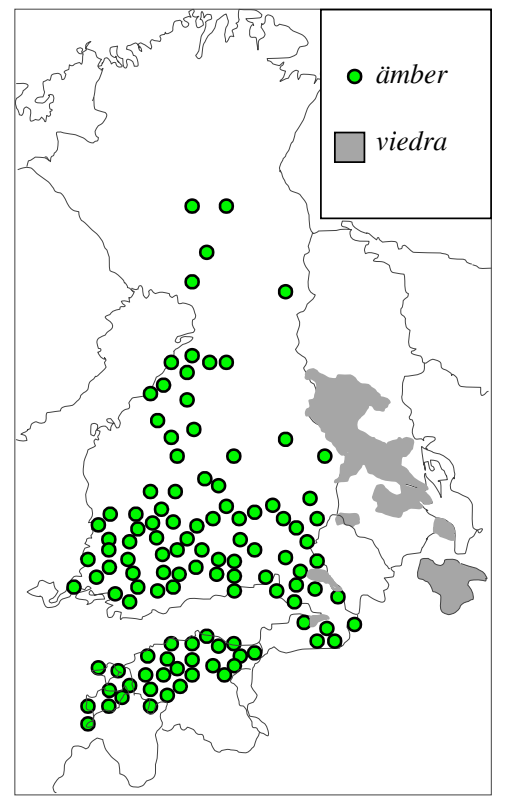

Joonis 3. ämber ja viedra (vt ALFE 1: 198)

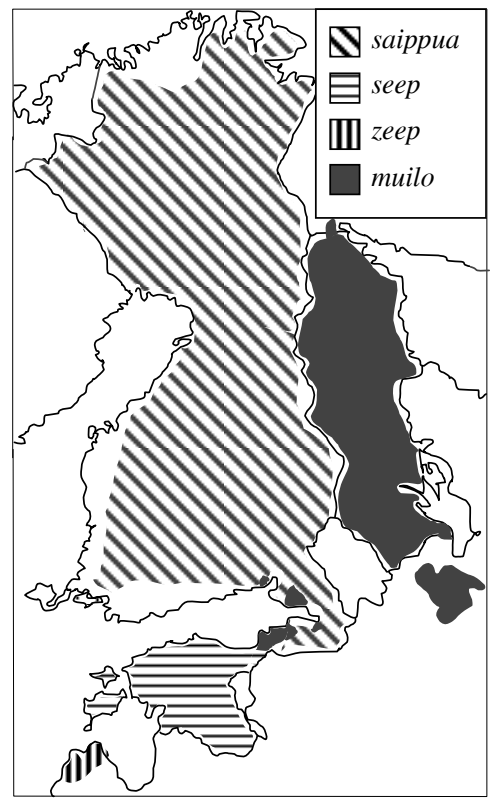

Joonis 2. 'seep' (vt ALFE 1: 200)

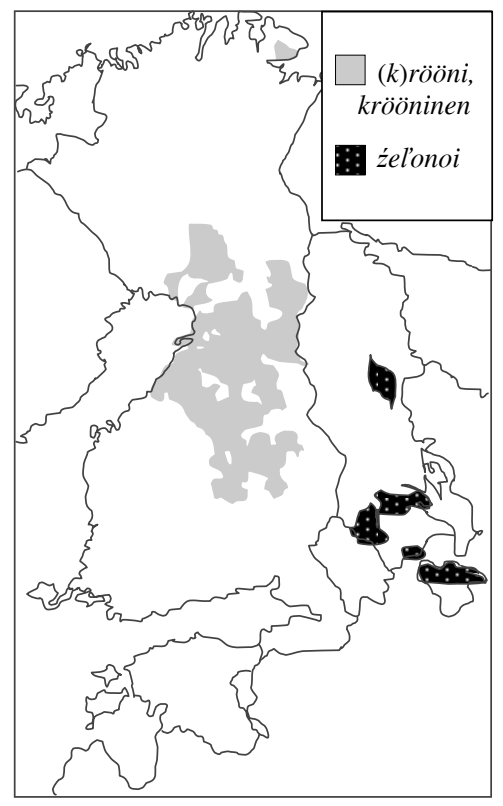

Joonis 4. krööni ja źelonoi (vt ALFE 2: 279) 
Keelekaartide analüüs ja keelendite leviku võrdlus aitab sageli tuua selgust keelenähtuste määratlemisel ning näha mõndagi uues valguses. Kui genuiinseks tuletiseks või deskriptiivseks peetud sõna esineb ainult läänemeresoome äärealal või teatud laenude traditsioonilisel levikualal, on mõnigi kord põhjust otsida sõna võimalikku sugulust või analoogiat indoeuroopa leksikast. Häälikuliste laenude kõrval leidub murretes tõlkelaene, mis tulevad esile just võrdluses naaberkeelte ainesega.

\section{Viidatud kirjandus}

Aalto, Marja 2008. Hyötytarha. - Botanian puutarhapalsta, 9/o8. http://www.joensuu.fi/ botania/heili/hyotytarha.html (1.02.2011).

ALE = Atlas Linguarum Europae (ALE). Volume I, 1-7. Commentaires. Cartes. Assen, Maastricht: Van Gorcum 1983-1990; Roma: Istituto Poligrafico e Zecca dello Stato, 1997-2007.

ALFE $=$ Atlas Linguarum Fennicarum. Itämerensuomalainen kielikartasto. Läänemeresoome keeleatlas. Ostseefinnischer Sprachatlas. Лингвистический атлас прибалтийскофинских языков. ALFE 1-3. Tuomo Tuomi (Peatoim.), Seppo Suhonen, Tiit-Rein Viitso, Vladimir Rjagojev (Toim.). Suomalaisen Kirjallisuuden Seuran toimituksia, 800/1295. Kotimaisten kielten tutkimuskeskuksen julkaisuja, 118/159. Helsinki: Suomalaisen Kirjallisuuden Seura, Kotimaisten kielten tutkimuskeskus, 2004-2010.

Ariste, Paul 1933. Eesti-rootsi laensõnad eesti murretes. Acta et Commentationes Universitatis Dorpatensis. B XXIX, 3. Tartu.

Beltechi, Eugen; Mocanu, Nicolae 1997. Chou (QI: 75), carte onomasiologique. - ALE I, 7. Commentaires, 131-146.

Bubrih 1997 = Бубрих, Д. В.; Беляков, А. А.; Пунжина, А. В. 1997. Диалектологический атлас карельского языка. Karjalan kielen murrekartasto. Venäjän tiedeakatemian Karjalan tiedekeskuksen Kielen, kirjallisuuden ja historian instituutti. Kotimaisten kielten tutkimuskeskus. Leena Sarvas (Toim.). Kotimaisten kielten tutkimuskeskuksen julkaisuja, 97. Helsinki: Suomalais-Ugrilainen Seura.

Buck, Carl Darling 1988 [1949]. A Dictionary of Selected Synonyms in the Principal IndoEuropean Languages. A Contribution to the History of Ideas. Chicago, London: The University of Chicago Press.

EEW = Mägiste, Julius 1982-1983. Estnisches etymologisches Wörterbuch. Helsinki: Finnisch-Ugrische Gesellschaft.

ENE = Eesti nõukogude entsüklopeedia, 3-4. Tallinn: Valgus, 1988-1989.

Harva, Uno 1932. Karjalaista kansanuskoa ja palvontaa. - Iivo Härkönen (Toim.). Karjalan kirja. Toinen, kokonaan uudistettu painos. Porvoo, Helsinki: WSOY, 469-482.

Kalima, Jalo 1952. Slaavilaisperäinen sanastomme. Tutkimus itämerensuomalaisten kielten slaavilaisperäisistä lainasanoista. Suomalaisen Kirjallisuuden Seuran toimituksia, 243. Helsinki: Suomalaisen Kirjallisuuden Seura.

Kettunen, Lauri 1940. Suomen murteet III, A. Suomen murrekartasto, B. Selityksiä murrekartastoon. Suomalaisen Kirjallisuuden Seuran toimituksia, 188. Helsinki: Suomalaisen Kirjallisuuden Seura.

Kettunen, Lauri 1960. Suomen lähisukukielten luonteenomaiset piirteet. Mémoires de la Société Finno-ougrienne, 119. Helsinki: Suomalais-Ugrilainen Seura.

Laanest, Arvo 1975. Sissejuhatus läänemeresoome keeltesse. Keele ja Kirjanduse Instituut. Tallinn: Eesti NSV Teaduste Akadeemia.

Laanest, Arvo 1995. Relikte und Innovationen im ostseefinnischen Wortschatz. - Itämerensuomalaisen kielikartaston symposiumi. FU 8 Jyväskylä 12.8.1995. Helsinki: Kotimaisten kielten tutkimuskeskus, 81-106. 
Laanest, Arvo 200o. Käsitteet 'sairastaa' ja 'rukoilla'. - Vilja Oja, Seppo Suhonen (Toim.). Studia ad geographiam linguarum pertinentia. Eesti Keele Instituudi toimetised, 6. Tallinn: Eesti Keele Sihtasutus, 38-49.

Leskinen, Heikki 1992. Karjalan kielikartasto I. Idän ja lännen sanastoeroja. Jyväskylän yliopiston suomen kielen laitoksen julkaisuja, 35. Jyväskylä: Jyväskylän yliopisto.

Must, Mari 2000. Vene laensõnad eesti murretes. Tallinn: Eesti Keele Sihtasutus.

Neetar, Helmi 2005. Foneetiline ja grammatiline info keeleatlases Atlas Linguarum Fennicarum (ALFE). - [Nina Zaitseva (Toim.).] Прибалтийско-финское языкознание: лингвогеографические исследования. Карельский научный центр. Российская академия наук. Институт языка, литературы и истории. Петрозаводск: Карельский научный центр РАН, 38-47.

Oja, Vilja 2003. A geolinguistic comparison of some Finnic lexical issues. - Linguistica Uralica, XXXIX, 2, 81-91.

Ojansuu, Heikki 1922. Eesti etümoloogiad. - Eesti Keel, 4-5, 137-139.

Raag, Raimo 1988. Nunn, prilla, koka ja teised. Eesti keele rootsi laensõnadest. - Keel ja Kirjandus, 11, 655-664; 12, 725-732.

Saareste, Albert 1924. Leksikaalseist vahekordadest eesti murretes I. Acta et Commentationes Universitatis Dorpatensis. B VI, 1. Tartu.

Saareste, Andrus 1938. Eesti murdeatlas. Atlas des parlers estoniens. I vihik. 28 kaarti. Tartu.

Saareste, Andrus 1941. Eesti murdeatlas. Atlas des parlers estoniens. II vihik. Kaardid 29-66. Tartu.

Saareste, Andrus 1955. Petit Atlas des parlers estoniens. Väike eesti murdeatlas. Skrifter utgivna av Kungl. Gustav Adolfs Akademien Nr 28. Uppsala: Almqvist \& Wiksells.

Sajavaara, Kari 1986. Aspects of English influence on Finnish. - Wolfgang Viereck, WolfDietrich Bald (Eds.). English in Contact with Other Languages. Studies in honour of Broder Carstensen on the occasion of his 6oth birthday. Budapest: Akadémiai Kiadó, 65-77.

SKES = Suomen kielen etymologinen sanakirja. Tutkimuslaitoksen Suomen suvun julkaisuja III. Lexica Societatis Fenno-Ugricae 12. Helsinki: Suomalais-Ugrilainen Seura, $1955^{-1978 . ~}$

SSA = Suomen sanojen alkuperä: Etymologinen sanakirja. Suomalaisen Kirjallisuuden Seuran toimituksia, 556. Kotimaisten kielten tutkimuskeskuksen julkaisuja, 62. Helsinki: Suomalaisen Kirjallisuuden Seura, Kotimaisten kielten tutkimuskeskus, 1992-2000.

Suhonen, Seppo 1973. Die jungen lettischen Lehnwörter im Livischen. Suomalais-Ugrilaisen Seuran toimituksia, 154. Helsinki: Suomalais-Ugrilainen Seura.

Suhonen, Seppo 2005. Omaa ja vierasta karjalan ja vepsän sanastossa ALFE I:n kartoissa. - [Nina Zaitseva (Toim.).] Прибалтийско-финское языкознание: лингвогеографические исследования. Карельский научный центр. Российская академия наук. Институт языка, литературы и истории. Петрозаводск: Карельский научный центр РАН, 16-26.

Škofic, Jožica 2009. Words for potato in Finnic languages in Atlas Linguarum Europae. - Marja Kallasmaa, Vilja Oja (Toim.). Kodukeel ja keele kodu / Home language and the home of a language. Pühendusteos Helmi Neetarile 75. sünnipäevaks 29. jaanuaril 2009. Eesti Keele Instituudi toimetised, 13. Tallinn: Eesti Keele Sihtasutus, 225-236.

Tuomi, Tuomo 2004. Sissejuhatus. - ALFE 1, 24-36.

Tuomi, Tuomo 2005. Kielikartta tutkimusvälineenä. - [Nina Zaitseva (Toim.).] Прибалтийско-финское языкознание: лингвогеографические исследования. Карельский научный центр. Российская академия наук. Институт языка, литературы и истории. Петрозаводск: Карельский научный центр РАН, 6-15.

Tuomi, Tuomo 2009. Itämerensuomalaisten kielten sanastollisista innovaatiokeskuksista. - Marja Kallasmaa, Vilja Oja (Toim.). Kodukeel ja keele kodu / Home language 
and the home of a language. Pühendusteos Helmi Neetarile 75. sünnipäevaks 29. jaanuaril 2009. Eesti Keele Instituudi toimetised, 13. Tallinn: Eesti Keele Sihtasutus, 251-264.

Vaba, Lembit 1997. Uurimusi läti-eesti keelesuhetest. Tallinn: Eesti Keele Instituut, Tampere: Tampereen yliopiston suomen kielen ja yleisen kielitieteen laitos.

Viitso, Tiit-Rein 1985. Läänemeresoome murdeliigenduse põhijooned. - Keel ja Kirjandus, 7, 399-404.

Viitso, Tiit-Rein 2005. ALFE ja keeleajalugu. - [Nina Zaitseva (Toim.).] Прибалтийскофинское языкознание: лингвогеографические исследования. Карельский научный центр. Российская академия наук. Институт языка, литературы и истории. Петрозаводск: Карельский научный центр РАН, 48-57.

VMS = Väike murdesõnastik, II. Valdek Pall (Toim.). Eesti NSV Teaduste Akadeemia. Keele ja Kirjanduse Instituut. Tallinn: Valgus, 1989.

Wiedemann, Ferdinand Johann 1973. Eesti-saksa sõnaraamat. Neljas, muutmata trükk teisest, Jakob Hurda redigeeritud väljaandest [1893]. Tallinn: Valgus.

Vilja Oja (Eesti Keele Instituut) peamised uurimisvaldkonnad on dialektoloogia, geolingvistika, läänemeresoome keeled. Eesti murrete sõnaraamatu koostajaid ja toimetajaid, Läänemeresoome keeleatlase ja Euroopa keelte atlase autoreid.

vilja.oja@eki.ee 


\section{ON THE LINGUISTIC AND CULTURAL CONTACTS OF THE FINNIC PEOPLES AS REVEALED IN THE AREAL DISTRIBUTION OF LOANWORDS}

\section{Vilja Oja}

Institute of the Estonian Language

Two linguistic atlases - the Atlas Linguarum Fennicarum (ALFE) and the Atlas Linguarum Europae (ALE), enable us to follow the post-formational contacts of all Finnic languages. The causes and trajectories of lexical innovation are, in most cases, to be found in extralinguistic factors. New words are usually adopted together with cultural innovations. Close contacts with several Indo-European languages are written into the geographical position of the Finnic languages: East-Slavic languages are spoken in the East, Baltic in the South, Germanic in the North and West. The centres and trajectories of linguistic innovations have a great deal to do with trade. During the Middle Ages the eastern centres of the Hanseatic transit trade between Russia and Western Europe were situated in Estonia and Livonia, and these also became centres of cultural and linguistic innovation. An important trade and communication centre of the Ladogan area was Korela, situated on the Karelian Isthmus. Many Scandinavian loanwords have travelled to Finnish across the Gulf of Bothnia, to spread on along the river Oulu, in some cases up to the southeastern dialects of Finnish.

The historical wars waged by the big neighbouring powers of the Finnic territories have resulted in the division of the Finnic area into spheres of Western and Eastern influence. Finnish has acquired most of its Indo-European loanwords via Swedish, while for Estonian and Livonian the main source has been German or Low German. In Karelian and Vepsian we encounter Russian loans above all. The contact zone of East and West is revealed in many maps of ALE and ALFE, while south of the Gulf of Finland we find a relatively large number of Russian loans besides the German ones. The source language depends, of course, on the concept as well as on the time of borrowing. Comparison of linguistic maps and analysis of the areal distribution of words may often explain linguistic phenomena and help to specify the origin of words.

Keywords: Indo-European loanwords, linguistic atlases, linguistic contacts, lexical maps, dialectism, Finnic languages 